\title{
18 A Typology of Votive Offerings: Observations Regarding a Sacred Area on the Piano del Tamburino, Himera
}

\begin{abstract}
The Institute of Mediterranean Archaeology at the University of Bern has conducted archaeological investigations since 2012 on the Piano del Tamburino in the territory of the Greek colony of Himera. This project has brought to light the substantial remains of two sanctuaries.

This contribution presents a selection of the ritual contexts excavated so far, which exemplify the variety of these practices in terms of their multiple and complex functions.

By studying the different material remains together with archaeozoological and palaeobotanical samples, the ritual activities become a reliable data set for discussions about ancient social identity. This combination of material can be considered as a cultural marker.
\end{abstract}

Keywords: Himera, Piano del Tamburino, sacred area, ritual practices, votive deposit

In this brief overview I shall be looking at some research results concerning votive offerings that have come to light in Himera on the 'Piano del Tamburino' (Sicily). Led by the Institute of Mediterranean Archaeology at the University of Bern, the excavation on the Piano del Tamburino (in progress since 2012) has uncovered two sanctuaries (Area 11, Area 12) in the territory of the ancient Greek colony. ${ }^{1}$

My research ${ }^{2}$ focuses on the analysis of the rituals and their dynamics as well as on understanding of the spaces associated with religious activities by examining the traces of ritual materiality found during excavations.

The dimension of ritual dynamics is a significant criterion for understanding a community; it touches upon a number of fundamental functional aspects, from spatial structure and management to the definition of a colony's identity over time. ${ }^{3}$ The analysis of the archaeological data, remains and traces of a material culture that can shed light on religious practices and meanings, is made more complex by the fact that there

1 For an overview of the excavation's findings to date, see Elena Mango's article in this volume (with older literature).

2 The PhD project that the author is leading at the University of Bern, under the supervision of Prof. Elena Mango.

3 Bell 2009, XIVf.; Lippolis - Parisi 2012, 426f., see also 425, footnote 14.

Ә Open Access. (C) 2020 Marcella Boglione, published by De Gruyter. (c) BY-NC-ND This work is licensed under a Creative Commons Attribution-NonCommercial-NoDerivatives 4.0 International License.

https://doi.org/10.1515/9783110498783-019 
are elements involved that are perhaps no longer evident ${ }^{4}$ or where not necessarily material in nature. This study investigates not only the possible role played by each consecrated object consciously deposited within the sacred area, but also the topographical and cultural context in which various other ritual activities took place.

Area 11 and Area 12 on the Piano del Tamburino, which are still under investigation, have yielded traces of a large number of sacred ritual activities. ${ }^{5}$ The focus of this paper will be on Area 12 (Fig. 1). This area has revealed the remains of materials that can be identified with a microcosm of more than fifty ritual activities and depositional actions to date, thus shedding new light on the nature of sacred and votive offerings in Himera. The examination and reflection on the presence and nature of these types of religious manifestations can lead to a better understanding of the character of the divinities venerated, their cults and the community using the sanctuary.

The methodology for investigating these 'votive groups' focuses firstly on them as single entities in correlation with the ritual dimensions in which they were employed and secondly, in with their identification within different typologies. The classification is based on the observation that the entire aspect of a deposit, as well as the physical deposition of an object, depends on cultural and spatial and temporal elements. The criteria employed to classify the votive units are based on their structural, spatial and functional aspects, on their chronology and their contents. Moreover, special attention is directed to the analysis of the functional nature of these votive units in order to be able to differentiate between deposits of foundation, divestment (for the meaning of this term cf. below), abandonment, and the like as well as ritual actions.

Votive depositions have been identified both within the south building (Fig. 1) as well as exterior to it, in the so-called open space, a large hypaethral zone north of the mentioned building. Three altars (M103, ST4 and ST43) have been identified in this area to date around which ritual actions under examination took place (Fig. 2).

\section{Some Deposition Categories}

In 2014, a bothros (ST11, Fig. 1) ${ }^{6}$ - a term I herewith would like to substitute with the term divestment deposit - was excavated. ST11 shows an irregular circular shape discovered in a space delimited by ST41 (most likely an additional altar) and wall M104; it contained numerous fragments of moulds of various terracotta products and terracotta

4 Osanna 2004, 45: the rituals may not leave physical traces.- In Gela, i.e., empty pits, Ardovino 1999, 175.

5 See footnote 1.

6 Mango 2015, 197-199. 


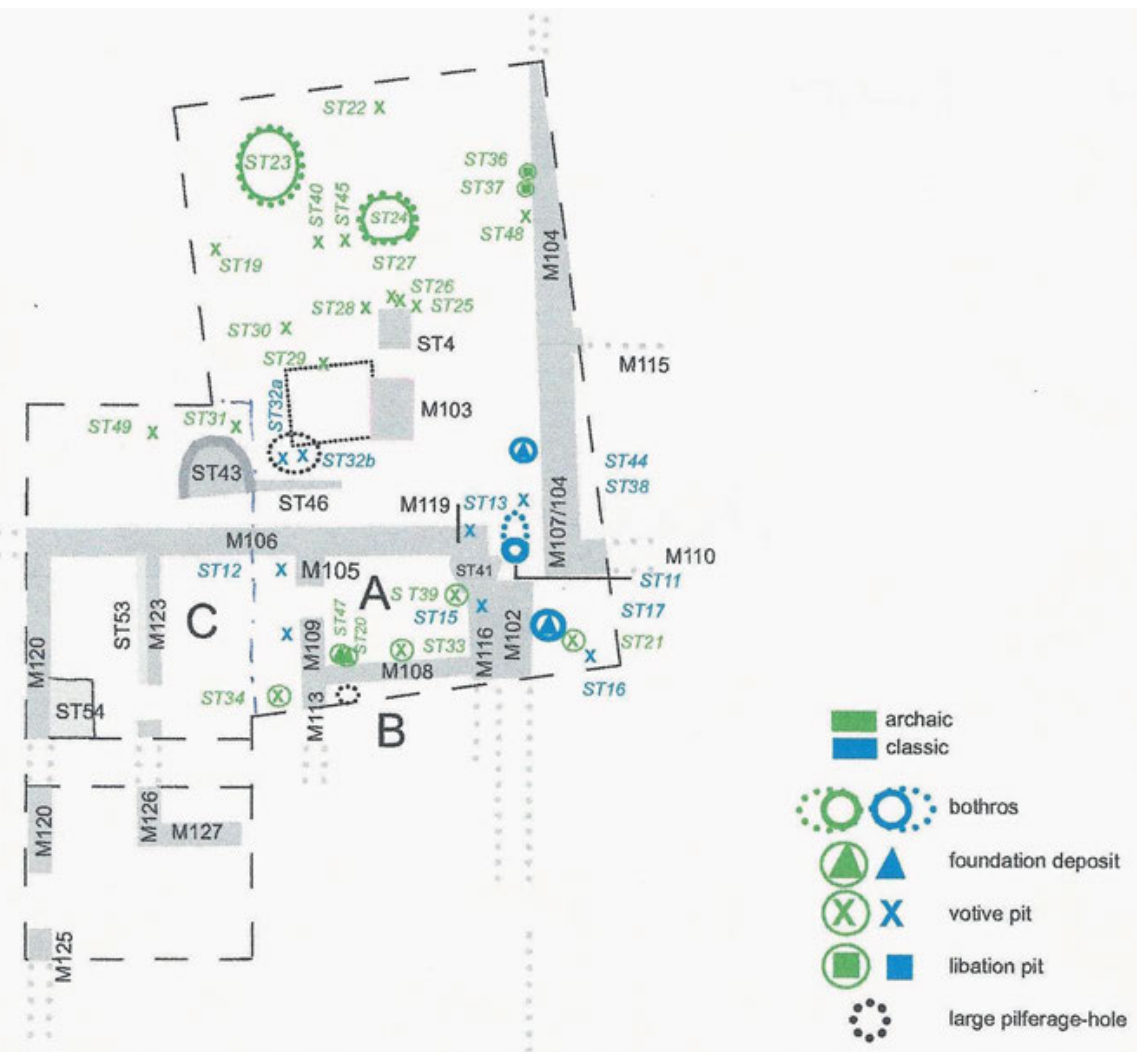

Fig. 1: Himera, Piano del Tamburino. Schematic plan of Area 12 with structures (Photo IAW@).

figures of different sizes, ${ }^{7}$ ceramic, a considerable amount of tile fragments mixed with pieces of charcoal and one little shell. The clearly differentiated categories of offering materials as well as their condition (for example, fragmentation, selection of only a part of a vessel and the shapes of the fragments), confirm its function as a divestment deposit. ${ }^{8}$ The same peculiar fragmentation of some metal fragments, found in ST11 (miraculously spared from the nocturnal activities of grave robbers), also corroborate this interpretation. Preliminary analyses of the contents of this structure suggest a deposition date towards the end of the $5^{\text {th }}$ cent. B.C.

Another category, well recorded in Area 12, is the foundation deposit, which is characterized by close spatial and chronological relation to the structures to which it

7 The coroplastic of the Piano del Tamburino is subject of the dissertation project currently underway of Matthias Edel (University of Bern).

8 Lippolis - Parisi 2012, $440 f$. 


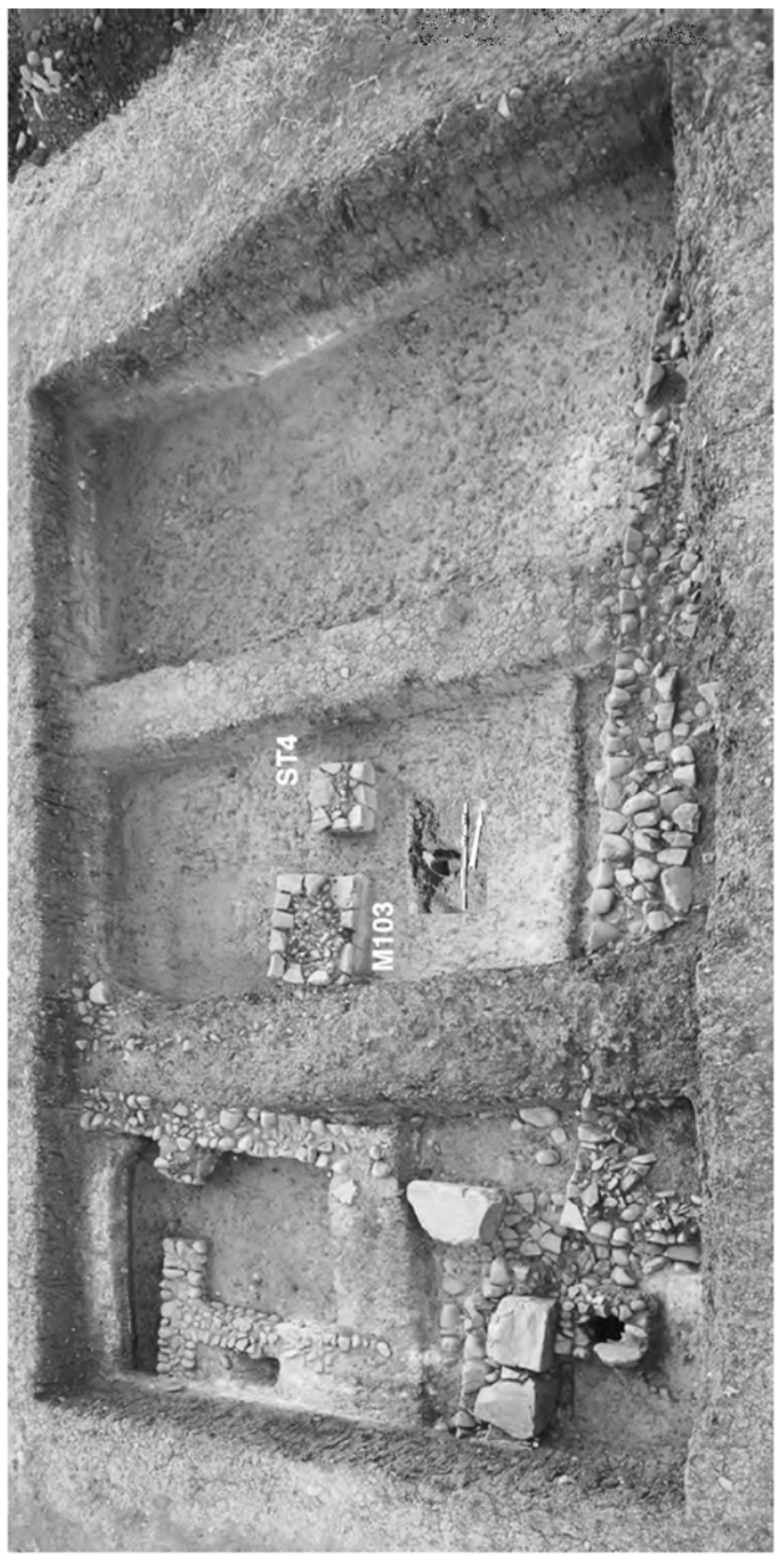


refers (Fig. 1). ${ }^{9}$ This is the case, for example, with ST17 (with a diameter of some $40 \mathrm{~cm}$ and a depth of $56 \mathrm{~cm}$ ) framed by a circle of large pebbles and small rocks located in relation to wall M102 running north - south. A frame of stones as a structural element with signal marking on the surface is also present in other structures on the Piano del Tamburino that most likely are not foundation deposits. This marker on the surface therefore seems not to be exclusive for foundation deposits. On the contrary, questions arise as to the 'why' of the marking of ST17? What was its purpose? Were there possibly multiple functions for this deposit? In addition to shells, charcoal remains, vessel parts (as pars pro toto - the majority of which are open shapes and cooking ware dating to the middle of the $5^{\text {th }}$ cent. B.C.) and other ceramic fragments which have been smashed to very small pieces suggesting ritual fragmentation. This last element, the ritual fragmentation, is to be considerate an additional action that took place before the 'deposition'. It is also noteworthy, that rim fragments of two different Punic amphorae were found, one at the bottom and the other on the top of the pit, ${ }^{10}$ as if they somehow delimited its content.

Another category are marks of ritual manifestations on the surface of the soil levels. These cases of ritual activities are well exemplified by the structures ST36 and ST37 in front of one of the passages formerly closed in by wall M104, which had been blocked before the ritual action had taken place (Fig. 1). A comparison of the two assemblages of the contents of these structures shows similarities that suggest comparable manners of deposition of votive offerings: items such as jugs, hydriai, cups and skyphoi, iron fragments, organic remains (bones, teeth) as well as charcoal traces. Another parallel is the fact that the bottoms of two vessels (a skyphos in ST36 and a hydria in ST37) show intentional perforations. This is probably related to libation practices associated with divinities with a chthonian connotation with the use of pouring liquids directly into the earth and the practice of leaving the vessel employed in an inverted position in the place where the libation took place. ${ }^{11}$ The libation is a 'single moment ritual action' which is perhaps related to the closure of the passage in M104 that they lie in front of. ${ }^{12}$ ST36 and ST37 are to be dated to the last quarter of the $6^{\text {th }}$ cent. B.C.

The data briefly summarised in this paper constitute only a very small selection from the more than 50 examples of ritual actions found in Area 12 to date. Nonetheless, the examples presented cover both the $6^{\text {th }}$ and the $5^{\text {th }}$ cent. B.C. and are representative for a wide range of different votive typologies.

Despite the lack of any epigraphic evidence, further study of the functional, structural as well as spatial aspects (inside, outside, next to the altars, etc.) of depositions will shed light on the rituals executed inside this sanctuary, the different divinities and

\footnotetext{
9 Lippolis - Parisi 2012, 444.

10 Mango - Edel 2016, 114 fig. 2. 118.

11 Osanna 2004, 58f.

12 Mango - Edel 2017, 117, footnote 18.
} 
their characters which were most likely venerated in this sacred area and will also help to characterize the communit(ies) frequenting the sanctuary. ${ }^{13}$

\section{References}

\section{Ardovino 1999}

A. Ardovino, Sistemi demetriaci nell'Occidente greco. I casi di Gela e Paestum, in: M.Castoldi (ed.), Koıva. Miscellanea di studi archeologici in onore di Piero Orlandini (Milano 1999) 169-188.

Bell 2009

C. Bell, Ritual Theory, Ritual Practice (New York 2009).

Mango - Edel 2016

E. Mango - M. Edel, Vierter Vorbericht zu den Forschungen in Himera (2015), AntK 59, 2016, $112-122$.

Mango - Edel 2017

E. Mango - M. Edel, Fünfter Vorbericht zu den Forschungen in Himera (2016), AntK 60, 2017, 113-123.

Lippolis - Parisi 2012

E. Lippolis - V. Parisi, La ricerca archeologica e le manifestazioni rituali tra metropoli e apoikiai, in: M. Lombardo, Alle origini della Magna Grecia. Mobilità, migrazioni, fondazioni. Atti del cinquantesimo convegno di studi sulla Magna Grecia, Taranto, 1-4 ottobre 2010 (Taranto 2012) 421-470.

Osanna 2004

M. Osanna, Rituali sacrificali e offerte votive nel santuario lucano di Torre di Satriano, ArchRel 6, 2004, 44-61.

13 Mango - Edel 2016, 120f. (e. g. the sanctuary of Siris - Herakleia). 